\title{
Editorial
}

\section{Mencari Sistem Hukum Indonesia yang Otentik}

Mencari dan menemukan sistem hukum Indonesia yang asli dan otentik, yang akan menjadi identitas sekaligus pedoman bangsa Indonesia dalam berhukum dan bernegara, tampaknya masih panjang dan berliku. Menemukan otentisitas sistem hukum Indonesia adalah usaha untuk menelusuri jejak kehidupan bangsa Indonesia dan nilai-nilai hukum yang dianut dan dipraktikkan dalam kehidupan bernegara dan bermasyarakat. Salah satu upaya yang harus dilakukan adalah dengan menggali tradisi hukum (legal tradition) yang pernah ada dan hidup dalam masyarakat Indonesia.

Ada tiga tradisi hukum utama yang memiliki pengaruh cukup penting dalam pembentukan dan perkembangan hukum di Indonesia, yaitu hukum adat, hukum Islam dan hukum Barat. Hukum adat pada dasarnya adalah tradisi hukum yang terbentuk berdasarkan nilai-nilai normatif masyarakat pribumi dan berkembang dalam masyarakat pribumi sesuai dengan rasa keadilan dan harmoni lokal. Tradisi hukum Islam adalah tradisi normatif yang datang ke Indonesia bersamaan dengan berkembangnya penyebaran Islam di wilayah tersebut. Ajaran Islam adalah hukum sakral yang diwahyukan Tuhan dan dipatuhi karena diyakini sebagai inti agama itu sendiri. Sementara itu, tradisi hukum Barat berkembang seiring dengan terjadinya kolonialisasi Belanda. Ketiga tradisi hukum inilah yang menjadi bahan baku pembentukan hukum Indonesia, yang dalam prosesnya ajaran-ajaran dan tradisi ini digunakan untuk menciptakan hukum baru yang berwajah Indonesia.

Tradisi hukum adat merefleksikan apa yang oleh sebagian pakar disebut sebagai tradisi hukum chthonic (tradisi hukum pribumi). Istilah chthonic berasal dari bahasa Yunani khthon atau khthononos yang berarti bumi. Dalam pengertian ini, hidup dengan cara pribumi berarti hidup dekat dengan bumi. Menggambarkan tradisi hukum Indonesia sebagai pribumi Indonesia adalah usaha untuk memotret tradisi yang berasal dari bumi Indonesia itu sendiri dan bukan dari luar. Hal ini bertujuan untuk memahami suatu tradisi berdasarkan kriteria internal dan bukan kriteria eksternalnya.

Polemik akademik yang kemudian muncul adalah mengenai posisi adat sebagai hukum. Terminologi adatrecht pertama kali dimasukkan dalam kosakata bahasa Belanda oleh Snouck Hurgronye, namun dikembangkan secara sistematik menjadi sebuah terminologi hukum oleh Van Vollenhoven dan Ter Haar. Dengan mengikuti pemahaman Barat mengenai hukum sebagai institusi (institution of sanction), Van Vollenhoven menganggap keberadaan elemen sanksi (sanksi adat) dalam adat sebagai kriteria untuk menerima adat sebagai hukum. Di pihak lain, Ter Haar 
mengidentifikasi adat sebagai bagian yang diterima sebagai hukum oleh pemangku adat. Untuk menjawab pertanyaan apakah adat adalah hukum, dari kedua pendekatan di atas tampaknya para sarjana Barat tersebut menggunakan kriteria positivistik Austinian yang mendefinisikan hukum sebagai aturan umum atau perintah yang ditetapkan oleh penguasa negara untuk para subjeknya dan ditegakkan dengan sanksi. Jika Van Vollenhoven konsisten mengikuti teori yang menegaskan keberadaan sanksi sebagai causa sine qua non yang sejati, maka Ter Haar cenderung mengikuti sudut pandang kedaulatan ketika memisahkan kebiasaan semata dari hukum adat yang sebenarnya (Ratno Lukito, Hukum Sakral dan Hukum Sekuler: 2008, hlm. 38).

Sarjana Belanda dengan gigih menganalisis adat dari sudut pandang positivisme hukum, yang dalam premisnya hukum adat dilihat dari aspek normatif semata dan sama sekali terpisah dari nilai-nilai moral dan etis yang ada di tengah-tengah masyarakat. Di lain pihak, para sarjana hukum Indonesia, memberi kesan bahwa mereka cenderung berkiblat pada ideologi hukum alam yang menempatkan argumen moral sebagai landasan utama bagi pembangunan hukum. Konsep hukum adat sebagai manifestasi keadilan, kepantasan dan nilai-nilai etis masyarakat sebagaimana digambarkan oleh pakar adat Indonesia seperti Soepomo, Djojodigoeno, Koesnoe, dan Hazairin merupakan cerminan dari pandangan mereka mengenai hukum adat dari sudut pandang hukum alam. Berdasarkan argumen ini, pemikiran mereka tentang adat tentu saja tidak akan menemui titik temu dengan cara pandang para sarjana Belanda, seperti halnya tidak akan pernah selesainya perdebatan filosofis antara mazhab hukum positivis dan mazhab hukum alam.

Tradisi hukum Islam di Indonesia tidak bisa dilepaskan dari proses masuknya agama Islam ke bumi Nusantara yang dilakukan relatif damai sehingga tidak mendapatkan resistensi kultural yang serius dan kemudian menjadi agama mayoritas penduduk Indonesia sampai saat ini. Perlahan tapi pasti, ajaran Islam menjadi bagian penting dari kehidupan masyarakat pribumi (Nusantara). Norma-norma Islam kemudian diterima dan dipraktikkan sebagai norma hukum. Pada masa kolonial Belanda, tradisi hukum Islam bahkan dijadikan elemen pembeda yang memisahkan masyarakat pribumi yang pada umumnya pemeluk agama Islam dengan masyarakat non-pribumi (Belanda dan Timur Asing).

Tradisi hukum Islam pada era kolonial sebagian besar berkaitan dengan persoalan privat sehingga relatif tidak mendapatkan resistensi kultural dari masyarakat pribumi. Di samping itu, salah satu kekuatan dari hukum Islam adalah sifatnya yang fleksibel dan adaptif dengan situasi setempat lewat mekanisme ijtihad yang dimilikinya. Dengan ijtihad, tradisi hukum Islam bukan saja dapat diterima, tapi juga dapat memberi jawaban atas persoalan hukum yang lahir akibat perkembangan kehidupan yang lebih modern. Sampai saat ini, tradisi hukum Islam tetap menjadi salah satu pemasok dan bahan baku hukum nasional, bahkan dalam hal-hal tertentu menjadi alternatif penting yang membuka kebuntuan misalnya berkaitan dengan ekonomi dan moneter lewat ekonomi dan bank syariah. 
Hukum Barat (dalam hal ini hukum Belanda) menjadi bagian dari alur sejarah dan pemikiran hukum di Indonesia sebagai akibat langsung dari penjajahan Belanda. Dari perspektif Savignian (Carl von Savigny) dengan aliran sejarahnya yang mengatakan bahwa, "Das rechts wird nicht gemacht, es ist und wird mit dem volke" (hukum itu tidak dibuat melainkan hidup dan berkembang di masyarakat), maka masuknya hukum Barat ini adalah sesuatu yang tidak dikehendaki. Savigny menolak pemberlakukan hukum Perancis yang ketika itu adalah bangsa yang menjajah Jerman. Bangsa Jerman tidak mau memberlakukan hukum Perancis. Hal yang sama berlaku untuk konteks Indonesia. Hukum Barat adalah bagian yang tidak terpisahkan dari penjajahan itu sendiri. Pemaksaan adalah jantung dan ideologi dari sebuah penjajahan. Dengan kata lain, hukum Barat masuk ke Indonesia lewat proses imposisi dan bukan dengan jalur akulturasi atau resepsi yang damai dan ikhlas.

Belanda pada awalnya memberikan pilihan kepada masyarakat pribumi apakah akan mematuhi hukum Belanda baik sebagian atau seluruhnya. Kemudian Belanda memperkenalkan prinsip kesesuaian (concordance) dengan menerapkan tradisi kodifikasi hukum dalam tradisi hukum pribumi. Hal ini kemudian diwujudkan dalam bentuk pemberlakuan hukum pidana, hukum perdata, dan hukum dagang dalam sistem hukum pribumi.

Ketiga tradisi hukum tersebut adalah akar dari sistem hukum Indonesia yang berlaku saat ini. Hukum Indonesia yang otentik tidak identik dengan hukum adat sebagai warisan kearifan masyarakat pribumi (masyarakat adat). Hukum Indonesia juga bukan merupakan fotokopi dari hukum Islam sebagaimana diterapkan di negaranegara Timur Tengah. Hukum Indonesia juga bukan hukum Belanda yang sepenuhnya berwajah kolonial karena seiring dengan perjalanan waktu, unsur-unsur kolonial secara bertahap sudah dihapus dari sistem hukum Indonesia. Singkatnya, otentisitas sistem hukum Indonesia adalah adonan dari nilai-nilai yang terkandung dalam ketiga tradisi hukum tersebut.

Agenda yang kemudian mengemuka dan mendesak untuk dilakukan adalah rekonstruksi pemikiran hukum. Pemikiran tentang hukum tidak terlepas dari konteks masyarakat tempat hukum tumbuh dan berkembang. Begitu pula dengan perkembangan pemikiran hukum di Indonesia, tidak terlepas dari perkembangan tatanan masyarakat Indonesia. Pada saat tatanan masyarakat kolonial berakhir dan berganti dengan tatanan masyarakat Indonesia yang merdeka, perdebatan mengenai orientasi pemikiran hukum mulai terjadi. Ada kelompok pakar yang menekankan pada kontinuitas hukum kolonial dengan penyesuaian-penyesuaian tertentu. Ada pula paham yang hendak memperjuangkan terwujudnya hukum nasional dengan cara mengangkat hukum masyarakat (hukum adat). Namun, paham-paham tersebut lebih menekankan pada politik hukum dalam fenomena transisi dari tata hukum kolonial ke tata hukum Indonesia pasca kemerdekaan. Dengan kata lain, perkembangan pemikiran pada masa itu belum mengarah pada pengembangan teori hukum atau ajaran filsafat hukum yang utuh dalam konteks keindonesiaan. 
Pemaparan di atas menunjukkan bahwa pengembangan pemikiran hukum, khususnya bangunan teori atau filsafat hukum yang bersifat keindonesiaan, belum menjadi tradisi di Indonesia. Walaupun terdapat benih-benih pemikiran hukum khas Indonesia yang digagas oleh beberapa pakar, namun dalam perkembangannya belum mengambarkan pemikiran hukum yang utuh yang berwajah dan ber-wijhah (berorientasi) Indonesia, termasuk dalam mengantisipasi kemerosotan praktik dari suatu pemikiran hukum. Hal ini merupakan alasan penting untuk merekonstruksi pemikiran hukum di Indonesia, setidak-tidaknya untuk mencari bangunan pemikiran hukum yang utuh dan otentik sesuai dengan perubahan masyarakat dan nilai-nilai keadilan yang tumbuh di Indonesia. Rekonstruksi dalam arti menemukan otentisitas sistem hukum Indonesia menjadi penting karena hukum bukan hanya sebagai identitas suatu bangsa tetapi juga sejarah bangsa itu sendiri. Dalam pengertian ini, rekonstruksi pemikiran hukum Indonesia harus dimaknai sebagai usaha untuk kembali kepada tradisi hukum Indonesia dengan melakukan kontekstualisasi terhadap nilai-nilai dalam tradisi hukum tersebut.

Artikel terpilih dalam Jurnal Padjadjaran edisi kali ini sedikit banyak mencerminkan upaya tiada henti dalam pencarian sistem hukum Indonesia yang otentik. Huala Adolf membuka dengan tulisannya mengenai sengketa investasi di ICSID. Sri Walny Rahayu menyodorkan penyelesaian sengketa adat Laut "Panglima Laôt" sebagai alternatif penyelesaian sengketa. M. Amirullah dan Aneke Putri Kusumawati membahas mengenai perlindungan merk terhadap Framing, Meta Tags, dan Deep Linking. Helni Mutiarsih Jumhur mengkaji mengenai perbandingan lembaga pengelola nama domain di Indonesia dan beberapa negara lain. Laina Rafianti dan Qoliqina Zolla Sabrina membahas mengenai perlindungan 'Kustodian' Ekspresi Budaya Tradisional Nadran. Hernadi Affandi dan Sri Hartini, Setiajeng Kadarsih, Tedi Sudrajat mengupas mengenai hak-hak politik pegawai negeri sipil. Rocky Marbun mengkaji mengenai politik dan sistem hukum pidana. Lilik Mulyadi mengkaji Perlindungan Hukum Whistleblower dan Justice Collaborator. Edisi ini kemudian diakhiri dengan bahasan Aditia Syaprillah dan Sapriani mengenai pengelolaan hutan lindung kota Tarakan dalam perspektif pembangunan berkelanjutan. Selamat menikmati, mengkaji, dan mengkritisi.

Bandung, Desember 2014 Redaksi 